\title{
Memorial music as a way of comprehension and dialogue through time and space
}

\author{
Aliona Zaozerskikh ${ }^{1 *}$, and Maria Chikhachyova ${ }^{1}$ \\ ${ }^{1}$ Dmitri Hvorostovsky Siberian State Academy of Arts, Department of Music History, 660049 \\ Krasnoyarsk, Russia
}

\begin{abstract}
This article is dedicated to the phenomenon of memorial music. Memoriality is characterized as one of the facets of cultural memory. The methodological basis of the work was made up of works dedicated to the "memory of culture" (J. Assman, P. Nora, J. Lotman) and musical memoriality (T.S. Andruschak, M.N. Lobanova, E.V. Nazaikinsky, O.V. Sokolov, N.L. Sokolvyak, V.N. Kholopova). The results of the study were the identification of thematic complexes, characteristic features and coordinate system of memorial music. Particular attention is paid to the manifestation in memorial music of a certain chronotope, embodied through the principle of "creative dialogue" with the addressee of the memorial dedication. Analytical characteristics of the coordinate system of "music of memory" are given by the authors on the example of memorial music of Siberian composers, composers of the Krasnoyarsk region in particular.
\end{abstract}

\section{Introduction}

Preserving cultural memory is one of the most important tasks of art, including music. Music is a special way of knowing oneself and the surrounding world, "musical ontology provides a special musical vision of the world and the person in it" [1], and at the same time, a new creative reality, a musical picture of the world, standing independently.

The concept of "cultural memory" was developed in the works of philosophers and literary scholars, first of all, J. Assman [2], P. Nora [3], J. Lotman [4]. According to J. Assman, the first significant embodiment of cultural memory is the memory of the dead. It is natural that one of the facets of cultural memory is connected with the phenomenon of memoriality, the desire to perpetuate by means of art the memory of someone or something, to capture the personal perception of the features of the bygone (man, era), to express an emotional response to the lost, distant, irrevocable.

Memoriality as a phenomenon of emotional and aesthetic understanding of the events of the past, primarily, the memories of the people gone, was reflected in various forms of art.

For example, in architecture, the memorial genres include gravestones, tombstones, plaques, monuments, mausoleums (Taj Mahal in Agra, Lenin's Mausoleum in Moscow), memorial ensembles (Mars Field in St. Petersburg, a monument to the victims of fascism in

* Corresponding author: zaozerskikh51@gmail.com 
Buchenwald, and many others). In painting (iconography) and sculpture, an iconographic composition "Pieta" (Mourning of Christ by the Virgin Mary) can be attributed to the memorial subjects. In addition, painting contains such genres as a memorial landscape and a memorial portrait. In literature, memorial traditions are associated with obituaries, epitaphs, sometimes even with letters, memoirs and diaries. Memorial genres are present in choreography as well, for example, various mourning processions and mourning dances (sarabande, etc.).

Considering the development of memorial genres in music, it is necessary to mention their historical roots associated with the tradition of mourning. It can be stated that memorial genres (as well as mourning genres) "were born" within traditional rites ("rites of passage"), formalizing "the last journey" from the world of the living. As one of the key criteria for distinguishing between mourning and memorial genres, we can use presence or absence of direct connection with the ritual, applied, function. Mourning genres (lamentation, burial service, requiem, sarabande, mourning march and others) are integral parts of mourning ceremonies. Memorial music is indirectly related to the ritual: it is not part of one. The main goal of memorial musical genres is to preserve the memory of culture through the creation of a special musical picture of the world.

The appeal to the "music of memory" on the part of composers is based not only on their interest in this genre, but on the need to express personal experiences of loss, to pay tribute to a significant figure or event. Rooted in musical history, the memorial genres received intensive development in the 19th and 20th centuries, becoming an important thematic sphere of academic music.

For instance, Pyotr Tchaikovsky. Trio "À la mémoire d'un grand artiste"; Sergei Rachmaninov. Trio Elégiaque "In Memory of a Great Artist"; Dmitri Shostakovich. Trio No. 2 (dedicated to the memory of Ivan I. Sollertinsky); anumber of works by I.F. Stravinsky - Funeral Song composed to commemorate the death of Nikolai RimskyKorsakov, "The Fairy's Kiss", dedicated to the memory of P.I. Tchaikovsky, Variations Aldous Huxley in memoriam, Introitus. T.S. Eliot in memoriam, Requiem Canticlesto the memory of Helen Buchanan Seeger; R. Sessions. Canons (to the memory of Igor Stravinsky); P. Boulez. Rituel in memoriam Bruno Maderna; L. Nono. "No hay caminos, hay que caminar" for Andrej Tarkowskij; A. Pärt. Cantus in memory of Benjamin Britten; T. Takemitsu. "Twill by Twilight" dedicated to the memory of Morton Feldman; and many others.

In our opinion, memoriality in art can be seen as a fixation of a certain chronotope (artistic reflection of time and space in their unity, relationship and interaction (M.M. Bakhtin)). It is possible to reveal the originality of the chronotope of the memorial opus only with the support of a comprehensive interdisciplinary approach (at the intersection of philosophy, cultural science, literary studies and art studies) using methods of structuralfunctional and semantic analysis.

\section{Materials and methods}

As part of our work, we limit ourselves to appealing only to memorial music based on theoretical works containing justifications for musical memoriality (T.S. Andruschak, M.N. Lobanova, E.V. Nazaikinsky, O.V. Sokolov, N.L. Sokolvyak, V.N. Kholopova). When considering this phenomenon, different terms are used: "memoriality", "memorial genres", "memorial music", "music in memoriam", "memory music", etc.

Thus, V. Kholopova defines memorial music concept as a "special genre class". O. Sokolov considers memorial music phenomenon as a special "genre mood", emphasizing the importance of the embodiment of the "sadness of loss and reverence for the recipient and the bright memory of them" [5]. 
E. Nazaikinsky introduces the notion of musical "memorial monuments" as a special example of historical style associated with the names of outstanding musicians [6].

Here is the definition by M. Lobanova: "Memorial is a genre that embodies the memory in culture, it involves a direct link between different styles and periods of individual manners, it is based on the "recall technique" (...) and symbols establishing associations with the "past", "someone's word"" [7].

Specific figurative, informative and musical features of memorial music are analyzed in the doctoral theses by T. Andrushchak ("Memorial Russian Music of the Last Third of the 20th Century (to the study of the phenomenon)") [8] and N. Sokolvyak ("Memorial Quartet in Russian Music: History, Evolution, Style") [9].

Summing out the observations of researchers, we can single out the leading thematic spheres of the memorial music, such as: mourning, memories of the past, juxtaposition of the categories of "life" and "death", "current" and "past", "temporary" ("real") and "eternal" ("otherworldly").

The distinctive way of artistic realization of the memoriality in music is the principle of dialogue between the author and the recipient of the initiation ("mourning and mourned"), defining the system of coordinates of the embodied chronotope, namely: the temporal aspect (the juxtaposition of the categories "present" and "past") and the spatial aspect (the juxtaposition of the categories "reality" and "otherworldliness" and, in some cases, geographical factor).

\section{Results}

\subsection{Coordinate system of the memorial music: through time and space}

The historical path of memorial music allows us to deduce stable types of initiations, such as dedication to a loved one (friend, relative, teacher, etc.), dedication to the iconic figure of the era, dedication to a collective recipient (often in the context of tragic historical events). The most extensive group of initiations of memorial music is the dedications to the memory of creative figures (composers, artists, architects, sculptors, etc.).

The generalizing factor of all types of initiations in memorial music is the principle of dialogue, which sets the temporal and spatial boundaries of the "embodied plot" and also sets the vectors of the development of the musical statement.

We view this dialogue as a way of learning. The author of the memorial initiation acts as a bearer of cultural memory. His creative reflection is a gnoseological immersion in the system of coordinates of memorial music. The composer creates a musical picture of the world, each element of which correlates with the ideological center, the image of the recipient of the initiation. This image includes a creative portrait, and historical and style context, and emotional bitterness of loss, and understanding of the creative path of the recipient of the initiation (his contribution to the cultural heritage). At the same time, this picture of the world turns out to be a means of self-knowledge for the author: a reflection of his perception of the cultural memory and a new round of its representation.

The facets of the world of memorial music are thematic spheres such as mourning, remembrance of the past, juxtaposition of the categories "life" and "death," "present" and "past," "temporary" ("reality") and "eternal" ("otherworldliness").

Sustainable thematic spheres correspond to the range of means of musical expression, which allow to embody the designated coordinate system. We need to remark that we are considering established musical traditions in European art music.

Memorial music differs from a simple musical initiation, first of all, it is the reflection of the time distance (even minimal), which indicates the mourning nature of this genre. The 
main means of embodying the "memorial dialogue" between the time layers are such composer's methods and techniques as: monograms, citation, allusions, polystylism.

Musical monograms allow the author to identify participants in creative dialogue (regardless of historical distance), with each of the composers choosing his encryption key. Among the well-known monograms often featured in memorial initiations, we can mention: BACH (J.S. Bach), HAEsB (J. Brahms), ADSCHEBE (A. Schoenberg), DSCH (D.D. Shostakovich), ASCH (A.G. Schnittke).

The introduction of an exact quotation from the music of the recipient of the initiation to the memorial composition is a "voice from the past" in the creative dialogue created. At the same time, an allusion (intentionally altered quotes or quotes in new musical conditions) is perceived as a musical memory transformed because of the time distance.

The technique of polystylism becomes an important means of building a memorial dialogue. Thanks to polystylism, the musical style of the initiation era is intertwined in dialogue with the style of the contemporary author. It is both a dialogue of epochs and the "voices" of two creators.

Temporal coordinates of memorial music are realized in a special genre context of the mourning tradition or with the use of musical signs and symbols indicating the irretrievability of the departure of the recipient of the initiation. Often, the genre basis of such musical opuses is mourning genres: mourning marches or mourning dances (passacaglia, sarabande). To stable musical signs and symbols that give a mournful nature to the musical dialogue, we can include crying intonations (with the use of vibrato and glissando on the instrument), author's remarks (lamento, crying; doloroso, mournful; pietoso, touching), as well as musical-rhetorical figures of the Baroque era: for example, passus duriusculus, "hard move" (movement in semitones), a sign of a tense, tragic sound, a symbol of suffering; catabasis, a descending forward movement, a symbol of death; crucs, the figure of a cross (four differently directed notes), a symbol of the crucifixion, suffering on the cross; etc.

Spatial coordinates of memorial music are associated with the embodiment of the categories "reality" and "otherworldliness."

The "reality" category reflects the space of the author of the memorial. This space is characterized by such properties of the earthly as: emotional response, pulse, variability, temporality. The musical means of expressing these characteristics in memorial music are the following. Emotional response is expressed through a declamation type of intonation (as a personal statement of the author of the initiation), polar gradations of dynamics (from pppppp to ffffffffff), various examples of musical contrast. The pulsation, reflecting the earthly course of time, the transience and variability of life, is expressed through ostinato, mechanistic, measured and dotted rhythms, musical symbols of the clockwork or leaps.

The "otherworldliness" category acts as a space of the recipient of initiation with such attributes as: absolute peace, numbness, soaring, light. Musical embodiment of this category are: choral chant, transparent texture, spatial stereophonic effects, withdrawn sounds, non-vibrato technique. The musical analogue of the parameters "soaring" and "light" are: high register, solo, special timbres (for example, harpsichord, celesta, children's voices).

The contrast in the embodiment of spatial coordinates of memorial music is often expressed through the rethinking of traditional genres. For example, lullaby, elegy and waltz are given the meaning of "eternal sleep."

Thus, it can be said that the memorial music sets certain filters of consideration in the process of learning the memory of culture, which is reflected in the specifics of the chronotope of the memorial picture of the world. 


\subsection{Geographical specifics of memorial music}

Memorial music has occupied a special niche among genres of modern academic music. The rooting of this phenomenon in creative practice is confirmed by the wide geographical spread in the world in general and in Russia in particular.

The legitimate question is whether it is possible to speak about the manifestation of geographical (or regional) features of the "music of memory."

As part of the article, we suggest referring to the "coordinates" of memorial music on the example of the creative heritage of the composers of Siberia, a vast and original region, which is represented by a number of composer organizations that are part of the Union of Composers of Russia, in the cities: Abakan (Khakassia), Irkutsk, Kemerovo, Krasnoyarsk, Kyzyl (Tuva), Novosibirsk, Omsk, Ulan-Ude (Buryatia), Yakutsk (Sakha (Yakutia)).

A peculiar "surge" of interest in the works of memorial orientation in the Siberian region can be seen since the 1970s:

- Barnaul: E. Kravtsov. Concert "In memory of Igor Stravinsky" (1972);

- Irkutsk: V. Tikhonov. Impromtu in memory of L. Kasabov for chamber orchestra, Piece in memory of N.A. Nepomniaschy for folk orchestra, Elegy "Recollection" for a quartet of cellos in memory of the past and gone colleagues musicians;

- Krasnoyarsk: I. Belova. A play dedicated to Fyodor Veselkov (2019); V. Beshevli. Quartet No. 2 (dedicated to the memory of uncle E. Ganzherli) (1976), song "Zates in memory" in memory of V.P. Astafiev (2011); V. Karpenko . Trio No 1 in memory of B. Britten (1977), Fantasy for symphony orchestra in memory of Andrey Petrov (2007); O. Meremkulov. Composition for solo cello "In memory of the architect Matvey Kazakov" (1990); O. Prostitov. Symphony No 2 in memory of I. Stravinsky (1983), A symphonyconcert for a bayan with both preset chords and a free-bass system in memory of V. Zolotaryov (1985), Terzetto dedicated to victims of the events of October 1993 (1993), "Lamento in Memory of a Great Master" dedicated to the memory of Andrey Petrov (2007), "Lamento in memory of A.Yu. Bardin" (2012); I. Fleischer. String Quartet No 1 in memory of Alfred Schnittke (2000), Vocalise "In Memory of the Fallen" (2004), Brandenburg Fantasy in memory of Yu. Kramarov (2011), "Musical offering" in memory of I. Uryash (2014); Prelude in C Minor for String Quartet in Memory of Yu. Mazchenko (2019);

- Novosibirsk: Z. Blakher.Musical comedy "Do not say yes or no?" in memory of N.D. Gritsyuk (1977); G. Ivanov.Symphony No 1 "In Memory of My Parents" (1991-1992); S. Kravtsov. Quartet No 1 in memory of R. Teveleva (1993); Yu. Yukechev. Piano Trio No 3 in memory of I.I. Sollertinsky (1983), pieces "In Memory of Yu. Kramarov" (1983), "In Memory of V. Khlebnikov" (1987), "In Memory of A. Tarkovsky" (1987), "In Memory of J. Brodsky" (1996);

- Omsk: I. Kheifets. Trio-requiem for violin, cello and piano "In Memory of 6,000,000" (1985), Concert for cello and orchestra in memory of Pyotr Tchaikovsky (1988);

- Ulan-Ude: J. Batuev. Ballet "Eternal Flame" and Poem "In Memory of a Hero" (1976) dedicated to the memory of the Hero of the Soviet Union V. Borsoev; P. Damiranov. Sonata for cello and piano in memory of N. Damiranov (1985); Yu. Irdyneev. Quartet "Elegian Stanzas" in memory of the poet D. Ulzituev (1973), "Little Requiem" in memory of my deceased friends: poets, musicians and singers" (1989-1993); V. Usovich. Elegy in memory of G. Otradnova (1976).

The examples of the Siberian "music of memory" testify to the appeal of the following dedications: the memory of historical events, of close people, dedication to iconic figures of the era, first of all, to creative personalities. While matching with the general Russian types of dedications, the "music of memory" of composers of Siberia stands out with a special feature of preservation of the memory of regional culture. Often, iconic for the region figures, whose names are not always known on the scale of the country, become objects of 
cultural memory for musical compositions, however, these people have made a significant contribution to the formation of the cultural identity of the "small homeland".

For a more detailed characterization of the "coordinate system" of the memorial music of Siberia, we will turn to the creative heritage of one of the Siberian composer organizations, Krasnoyarsk one. We need to note that the Siberian memorial music of the 21 st century is chiefly represented by works of Krasnoyarsk composers.

Immersion into the coordinate system of the memorial music of Siberia allows to detect the main components of the chronotope of the memory music.

The manifestation of memorial dialogue in time are such techniques as monograms, quotations and allusions, signs of style. Krasnoyarsk authors introduce both monograms of the recipients of the initiation, and their own, which allows to identify participants of creative dialogue (for example, the composer V.E. Karpenko introduces his musical signature B-A-Dis-E-D: "Vladimir" in the interweaving of Latin letters and pronunciation in Cyrillic).

The introduction of quotations and allusions from the music of the recipients of the initiation allows us to "hear" the voice from the past; polystlism techniques recreate a certain historical context.

For example, each of the five parts of the concert-dedication to I.F. Stravinsky refers either to a certain style period of the composer's work (neoclassical, serial), or to the characteristic of a certain group of musical genres employed by Stravinsky (ballets, instrumental concerts). Addressing the genre of symphony-concert (memory of V.A. Zolotarev), O.L. Prostitov continues the tradition of Zolotarev in the creation of concert symphonies for bayan, and embodies the bright signs of the composer's style of the recipient of the dedication: appeal to twelve-tone serialism, polytechnics, complex forms of genre-style synthesis (e.g., the combination of twelve-tone serialism and Russian songwriting).

V.E. Karpenko builds a memorial dialogue with the composer A.P. Petrov through quotations of his waltzes from the famous Soviet films "Beware of the Car" and "Walking the Streets of Moscow".

An interesting example of work with polystylism is the memorial works of I.Ya. Fleischer. The composer in his memorial initiations introduces quotations and allusions from the music of J.S. Bach, as well as generalized features of baroque music. In this case, polystylism is used to designate not temporal, but spatial layers of the coordinate system. J.S. Bach's legacy is a symbol of the wonderful world of high musical ideals, the world of the addressee of initiation, or otherworld. We should note that, in general, when recreating the category of "otherworldliness" in music, Siberian authors turn to the main characteristics of this image in memorial music (spatial and stereophonic effects, lightening the timbre color, upper sound register).

An example of the manifestation through the quotation of the time and spatial coordinates of the "music of memory" chronotope is a quote from F.P. Veselkov's song "Meeting of Angara and Yenisei" in the play-lullaby of I.G. Belova. The quotation as the "voice" of the recipient of the initiation simultaneously acts as a geographical reference point, recreating the colorful image of the Siberian rivers.

As another example of the geographical specifics of the memorial music of Siberia, we can consider the song of V.A. Beshevli "Zates for memory" (dedicated to the memory of the outstanding Siberian writer V.P. Astafyev), in which a quote from the symphonic poem of the composer "Zatesi" (created based on the book by V.P. Astafyev) sounds. We should decipher that "zates" is a notch made on a tree with a sharp object, so as not to get lost, a kind of "forest memo".

A feature of the composer's dedications is the significance of a sense of personal loss in relation to the recipient of the dedication of "memory music". In most cases, we can talk 
about the closeness of the types of dedications: outstanding personalities of their time, regional culture and close people.

For example, O.L. Prostitov paid tribute to his colleague, artistic director of the Krasnoyarsk Regional Philharmonic, conductor of the orchestra of Russian folk instruments A.Yu. Bardin. I.G. Belova dedicated a commemorative opus to her teacher at the Krasnoyarsk School of Art, F.P. Veselkov. The dedication of I.Ya. Fleischer's "Brandenburg Fantasy" was a tribute to the memory of a friend, the violist Y.M. Kramarov, with whom they took to the stage together in Krasnoyarsk the day before the latter's death. Another memorial opus of I.Ya. Fleischer was addressed to his friend and teacher Yu.N. Mazchenko.

However, even in other dedications of memorial music of Krasnoyarsk composers, there is some personal story. For example, two Siberian memorial opus by O.L. Prostitov and V.E. Karpenko are dedicated to the composer A.P. Petrov. It was on his initiative, when he was chairman of the Leningrad Composer Organization, that in 1983 the Krasnoyarsk branch of the Union of Composers was opened, which had a great impact on the development of the art of the Siberian region.

Of interest is the story of the dedication of the Trio No. 1 by V.E. Karpenko to the memory of B. Britten. As a schoolboy, in 1972 V.E. Karpenko decided to write to a classic of English music and even received in response a letter with attached notes.

The opuses of Krasnoyarsk authors considered are vivid and original examples of the implementation of the idea of memoriality, acting as a connecting thread between regional and world creative levels in preserving the cultural memory. Thus, on the example of the "music of memory" of Siberia, it can be stated that "musical signs" of a particular territory and regional culture can act as geographical features of the chronotope of memorial music.

\section{Discussion}

A number of scientific studies are devoted to understanding the creative heritage of Siberian composers (among the authors: I.V.Belonosova [10], L.V. Gavrilova [11], S.S.Goncharenko, O.I. Kunitsyn, N.M. Naiko, L. L. Pylneva [12] and others). However, the role of memorial music in the works of Siberian composers has not yet been sufficiently studied [13-14]. This explains the novelty of the presented work.

Memoriality is an important theme in the musical compositions by Siberian composers. In general, this phenomenon reflects the all-Russian tendencies in the development of "in memoriam" music (genres, specific informative and musical features). Also this situation coincides with the searches of leading world composers in their memorial works.

\section{Conclusion}

Summing up, we would like to note that in the creative practice of world and Russian memorial music a system of certain thematic complexes, recognizable musical signs and symbols has been established. One of the key features of memorial music is the embodiment of the principle of creative dialogue, which can be considered as a kind of coordinate system of a memorial composition or a reflection of a certain chronotope. Gnoseological immersion in the creative world of the recipient of the dedication of the memorial work turns for the author (the bearer of the cultural memory) into a reflection of himself.

In Zatesi, a book by the outstanding Russian and Siberian writer V.P. Astafyev, there is a thought: "Life is not a letter, there is no postscript in it" [15]. We thing that the 
phenomenon of memoriality in art is aimed at creating this "postscript" as a memory of a person and his activities.

The project "Composers of Yenisei Siberia: history, cultural heritage and human perspectives of the region" was funded by Krasnoyarsk Regional Fund of Science.

\section{References}

1. A.B. Denisova, Existence of the musical image: An ontological-epistemological analysis [Bytie muzykal'nogo obraza: ontologo-gnoseologicheskij analiz]. Thesis for Dissertation for the Degree in philosophical studies, 4 (Kazan, 2000) (In Russ.)

2. Ya. Assman, Cultural memory. Writing, memory of the past and political identity in the high cultures of antiquity [Kul'turnaya pamyat'. Pis'mo, pamyat' o proshlom $\mathrm{i}$ politicheskaya identichnost' v vysokih kul'turah drevnosti] (Moscow, 2004) (In Russ.)

3. P. Nora, Realms of Memory, France-memory [Problematika mest pamyati, Franciyapamyat'] (St. Petersburg, 1999) (In Russ.)

4. Yu.M. Lotman, Memory in cultural coverage, Selected articles [Pamyat' v kul'turologicheskom osveshchenii, Izbrannye stat'i]. Vol. 1 (Tallinn, 1992). (In Russ.)

5. V.N. Kholopova, Music as a form of art [Muzyka kak vid iskusstva], 204 (Saint Petersburg, 2014) (In Russ.)

6. E.V. Nazajkinskij, Style and genre in music [Stil' i zhanr v muzyke] (Moscow, 2003) (In Russ.)

7. M.N. Lobanova, Musical style and genre: history and modernity [Muzykal'nyj stil' i zhanr: istoriya i sovremennost'], 168 (Saint Petersburg, 2015) (In Russ.)

8. T.S. Andrushchak, Memorial in the national music of the last third of the XX century (to the study of the phenomenon) [Memorial'nost' $\mathrm{v}$ otechestvennoj muzyke poslednej treti XX veka (k issledovaniyu fenomena)]. Thesis for Dissertation for the Degree of Candidate of Arts (Saratov, 2008) (In Russ.)

9. N.L. Sokol'vyak, Memorial Quartet in Russian music: history, evolution, style [Memorial'nyj kvartet v russkoj muzyke: istoriya, evolyuciya, stil']. Thesis for Dissertation for the Degree of Candidate of Arts (Magnitogorsk, 2014) (In Russ.)

10. I.V. Belonosova, Musical culture of Russian cities of Eastern Siberia [Muzykal'naya kul'tura rossijskih gorodov Vostochnoj Sibiri]. Monograph. Krasnoyarsk: Krasnoyarskij gosudarstvennyj institut iskusstv Publ., 2015. P. 380. (In Russ.)

11. L.V. Gavrilova (ed.), The musical culture of Krasnoyarsk [Muzykal'naya kul'tura Krasnoyarska], Vol. 3 (Krasnoyarsk, 2012) (In Russ.)

12. L.L. Pyl'neva, The processes of formation of the composers of Buryatia, Tuva and Yakutia [Processy stanovleniya tvorchestva kompozitorov Buryatii, Tyvy i Yakutii] (Novosibirsk, 2013) (In Russ.)

13. A.V. Zaozerskikh, M.M. Chikhachyova, "Memory of Culture" in Memorial Music by Siberian Composers, Advances in Social Science, Education and Humanities Research, volume 368. 3rd International Conference on Art Studies: Science, Experience, Education (ICASSEE 2019), p. 525-529. (In Eng.)

14. A.V. Zaozerskikh, M.M. Chikhachyova, Music of "memory" in the works of Siberian composers [Muzyka "pamyati" v tvorchestve kompozitorov Sibiri], Vestnik muzykal'noj nauki no. 1 (23), p. 98-104 (2019) (In Russ.)

15. V.P. Astafyev, Zatesi [Zatesi] (Krasnoyarsk, 2003) (In Russ.). 